Glasnik Antropološkog društva Srbije / Journal of the Anthropological Society of Serbia

Niš, vol. 49, str. 103-110, 2014, UDK 572(05), ISSN 1820-7936

UDK 617.7:574.3(497.113)

doi: $10.5937 /$ gads $1449103 \mathrm{P}$

\title{
PREVALENCE OF COLOUR BLINDNESS IN PROVINCE OF VOJVODINA - REPUBLIC OF SERBIA
}

\author{
Tatjana Pavlica, Verica Božić-Krstić, Rada Rakić, Damjana Drobac \\ University of Novi Sad, Faculty of Sciences, Department of Biology and Ecology, \\ Laboratory for Human Biology, Novi Sad, Serbia
}

\section{Summary}

The absence of one or more receptor types in the eye leads to colour blindness. The frequency of this anomaly varies between populations but also within different regions of a country. The aim of the study is to determine the frequency of colour blindness in the region of Vojvodina-Republic of Serbia. The study includes data obtained in the investigations conducted during the period 1996-2009. The total number of subjects is 14125 (6847 males; 7278 females). The Ishihara plates are applied as a common methodological procedure. In total, the frequency of colour-blind males and females is $5.62 \%$ and $0.34 \%$, respectively. As for a particular type of this deficiency, the results suggest that deutan deficiency prevails in relation to protan. Prevalence of colour blindness in all three regions of Vojvodina is very similar. The genetic heterogeneity of ethnic groups for this anomaly is relatively small. In comparison with earlier studies conducted in the region of Vojvodina, a slightly lower prevalence of daltonism is observed in the present population. The obtained results are within the limits set for European populations.

Key words: Colour blindness, protan, deutan, Vojvodina, ethnic groups.

\section{Introduction}

Colour blindness is a disorder of colour vision which is usually inherited condition, caused by a common $\mathrm{X}$ linked recessive gene passed from a mother to her son. Sometimes disturbances in the perception of colours may be acquired, usually due to damage and degeneration of the retina, optic nerve and brain, or cataracts. Some diseases can also cause colour deficits, as well as some medications or chemical exposure (American Optometric Association). The data on the prevalence of colour vision deficiencies in children and young people revealed no consistent agerelated trend in the proportion of individuals with a red-green visual defect (NHS, 1974), but the ability to see colours can gradually deteriorate as we grow old.

Dichromats are people blind to one of three colours: red, green or blue, and we can distinguish three different forms protanopia, deuteranopia and tritanopia. A significant number of people suffer from this anomaly, although the incidence varies in different geographic regions. Among Caucasians, about $8 \%$ of males and $0.5 \%$ of females have red-green colour vision defects, but among males of African (3-4\%) or Asian (3-5\%) origin, these defects are less frequent (NCHS, 2008). Recent surveys (Birch, 2012) suggest that the prevalence is rising in men of African ethnicity and in geographic areas that have been settled by incoming migrants. Based on a representative sample of different world populations (Sharpe et al., 1999 ) it was found that the protan type occurs in $2.09 \%$ of males and $0.05 \%$ of females and deutan type in $5.9 \%$ of males and $0.37 \%$ of females. The first large investigation of daltonism in Serbia was conducted in the region of Vojvodina in the seventies of the 20th century. The examination of the frequency of colour blindness in Nadalj in Bačka (Stajić, 1973) showed a 
frequency of $7.24 \%$, with $2.73 \%$ of it being protan and $4.51 \%$ deutan type. Among females none of the cases of this type of deficiency was recorded. In a later study, the same author (Stajić, 1976) examined total blindness in the population of Vojvodina and found that colour blindness occurred with an incidence of $7.40 \%$, and the differences between villages and ethnic groups were not significant. The aim of this study was to determine the frequency of colour blindness in the present population of Vojvodina, in certain geographic regions and among certain ethnic groups.

The Province of Vojvodina province represents the northern part of the Republic of Serbia. The parts of the Province of Vojvodina are Bačka, Banat and Srem. Bačka is in the central, Banat in the north-east part and Srem is located in southwest part of Vojvodina (Bukurov, 1978). According to the most recent population census (Census of Population, Households and Dwellings in the Republic of Serbia, 2011), there are 1,916,889 people living in Vojvodina. The population consists of different ethnic groups. The majority of the population is of Serbian nationality $(65.05 \%)$. Other major ethnic groups include the Hungarians (14.28\%), the Slovaks (2.79\%), the Croats (2.78\%), the Montenegrins $(1.75 \%)$, the Romanians (1.50\%), the Roma (1.43\%) and the Ruthenians (0.77\%) (Serbian Statistical Annual, 2003). All these ethnic groups settled here in the $18^{\text {th }}$ and $19^{\text {th }}$ century.

\section{Methods}

This paper uses data from different studies of colour blindness in Vojvodina, conducted in a 13-year period, from 1996 to 2009. The data include a total of 14125 individuals, 6847 males and 7278 females (Table 1).

Table 1. Total number of persons surveyed in individual studies

Tabela 1. Ukupan broj ispitanika u pojedinim istraživanjima

\begin{tabular}{lcrrrc}
\hline Region & Age & Males & Females & Total & Source \\
\hline Srem & $20-50$ & 900 & 859 & 1759 & Pavlica (1996) \\
Bačka and Banat & $>20$ & 1848 & 2534 & 4382 & Pavlica (2009) \\
Sajan and Mokrin & $>20$ & 286 & 303 & 589 & Tatić (2001) \\
Novi Sad & 20 & 849 & 762 & 1611 & Simić (2002) \\
Novi Sad & $8-16$ & 542 & 517 & 1059 & Drobac (2008) \\
Sombor & $9-16$ & 1208 & 1125 & 2333 & Bogosavljević (2008) \\
Melenci & $>10$ & 608 & 392 & 1000 & Karapandžin (2008) \\
Zrenjanin & $15-19$ & 287 & 280 & 567 & Markov (2008) \\
Zrenjanin & $15-19$ & 319 & 506 & 825 & Pejić (2009) \\
Total & \multicolumn{7}{c}{6847} & 7278 & 14125 & \\
\hline
\end{tabular}

The subjects are adults, students and children of different ages. The investigations made in Srem (Pavlica, 1996), Bačka and Banat (Pavlica, 2009) represent a comprehensive survey that included the entire area, while other data were taken from studies conducted in respective parts of Vojvodina.

The results of investigations presented in this paper are parts of bachelor thesis research (Drobac, 2008; Bogosavljević, 2008; Karapandžin, 2008; Markov, 2008; Pejić, 2009, master thesis (Pavlica, 1996; Tatić, 2001; Simić, 2004) and a doctoral dissertation (Pavlica, 2009). The theses can be found in the library of the Department of Biology and Ecology, University of Novi Sad.

All the data were acquired with the written consent of the Academic Council of Faculty of Sciences and Department of Biology and Ecology in Novi Sad. In the case of younger subjects, the data were collected with a consent of the headmaster of the school where the 
research took place. The subjects voluntarily participated in investigations. All applicable institutional regulations concerning the ethical use of human volunteers were followed during this research.

All the tests were performed by the same methodology using Ishihara colour test (Ishihara, 1965). The test is based on the ability to distinguish different colours and to perceive the degree of contrast among them. In this study the test included the most common innate deficiencies in colour recognition - red and green colour blindness, i.e. protan and deutan defect. The test was conducted in daylight. To prevent possible variations that different colour shades might cause, both direct sunlight and direct artificial light were avoided during the test process. The tables with patterns were placed at the distance of $75 \mathrm{~cm}$ from the subjects, at the right angle to the sightline. The numbers were clearly noticeable and the subjects were expected to respond within three seconds. In most of the cases it was not necessary to use the whole series of patterns. The table number 1 was always first to be shown as it introduces a subject with the testing process. The other tables were set as a trap to colour blind individuals. If a subject was able to distinguish the right number in 10 or more patterns, they were classified as individuals with normal vision. In the case when only 7 or less than 7 patterns were identified correctly, the subject was considered colourblind. In some cases it was impossible to clearly determine the type of colour blindness as the subjects were unable to distinguish colours. These cases were categorized as non-classified anomalies.

The data on the incidence of certain types of colour disorders are presented on the basis of the results of studies focusing on certain types of colour blindness. The frequencies for different types of colour disturbance were calculated in respect to total number of individuals who underwent this analysis. Statistical analysis was performed using the program SPSS 15.0 for Windows Evaluation Version. Significant difference between percentages was obtained by $\chi^{2}$ test with level of significance being $\mathrm{p}<0.05$ and $\mathrm{p}<0.01$. The prevalence of colour blindness among ethnic groups was made on the basis of Pavlica $(1996,2009)$ research determining the prevalence of colour disorders in the largest ethnic groups in Vojvodina. The frequency of recessive alleles related to total daltonism $(\mathrm{cv})$, protan $\left(\mathrm{cv}^{\mathrm{p}}\right)$ and deutan type $\left(\mathrm{cv}^{\mathrm{d}}\right)$ were calculated on the basis of relative frequency of the recessive phenotype. This analysis included only males, as in the ethnic groups of females only a few cases of colour disorders were detected. The degree of genetic distance of the ethnic groups was obtained by the analysis of standardized Wahlund variance of allelogenic frequencies (Cavalli-Sforza and Bodmer, 1971). Graphic outline of genetic relationship between the ethnic groups is given by a dendrogram.

\section{Results}

Prevalence of colour blindness in total population of males and females is shown in Table 2.

Table 2. Prevalence of colour blindness in total population of males and females

Tabela 2. Prevalenca kolornog poremećaja u ukupnom uzorku muškaraca i žena

\begin{tabular}{lcccc}
\hline Sex & & Normal & Colour blind & Total \\
\hline Males & $\mathrm{n}$ & 6462 & 385 & 6847 \\
& $\%$ & 94.37 & 5.62 & 100 \\
\hline Females & $\mathrm{n}$ & 7253 & 25 & 7278 \\
& $\%$ & 99.66 & 0.34 & 100 \\
\hline
\end{tabular}

It is noticeable that out of 6847 male subjects, colour disorder was ascertained in 385 individuals, i.e. in $5.62 \%$ of male subjects. A significantly lower percentage of the anomaly is recorded in women $(0.34 \%)$. There is also a significantly higher frequency of genes for 
colour blindness in men (0.056) than in women (0.000011), which is consistent with the known mode of inheritance of this anomaly.

Table 3. Prevalence of certain types of colour blindness in total population of males and females Tabela 3. Prevalenca određenih tipova kolornog poremećaja u ukupnom uzorku muškaraca $i$ žena

\begin{tabular}{lccccc}
\hline Sex & & Total & Protan & Deutan & Non-classified \\
\hline Males & $\mathrm{n}$ & 5712 & 63 & 152 & 100 \\
& $\%$ & 100 & 1.10 & 2.66 & 1.75 \\
\hline Females & $\mathrm{n}$ & 6213 & 0 & 4 & 18 \\
& $\%$ & 100 & 0.00 & 0.06 & 0.29 \\
\hline
\end{tabular}

The calculated frequencies for different types of colour disorders (Table 3) were made on the basis of the total number of patients who underwent this analysis. It is noticeable that in both sexes deutan type is more common than protan and the differences are statistically significant $(\mathrm{p}<0.01$ ). Approximately $2.66 \%$ of males and $0.06 \%$ of females do not distinguish green colour. As for the red colour, the anomaly is detected only in $1.10 \%$ of males. In the case of about $2 \%$ of males and $0.29 \%$ of females it was impossible to clearly determine the type of anomaly.

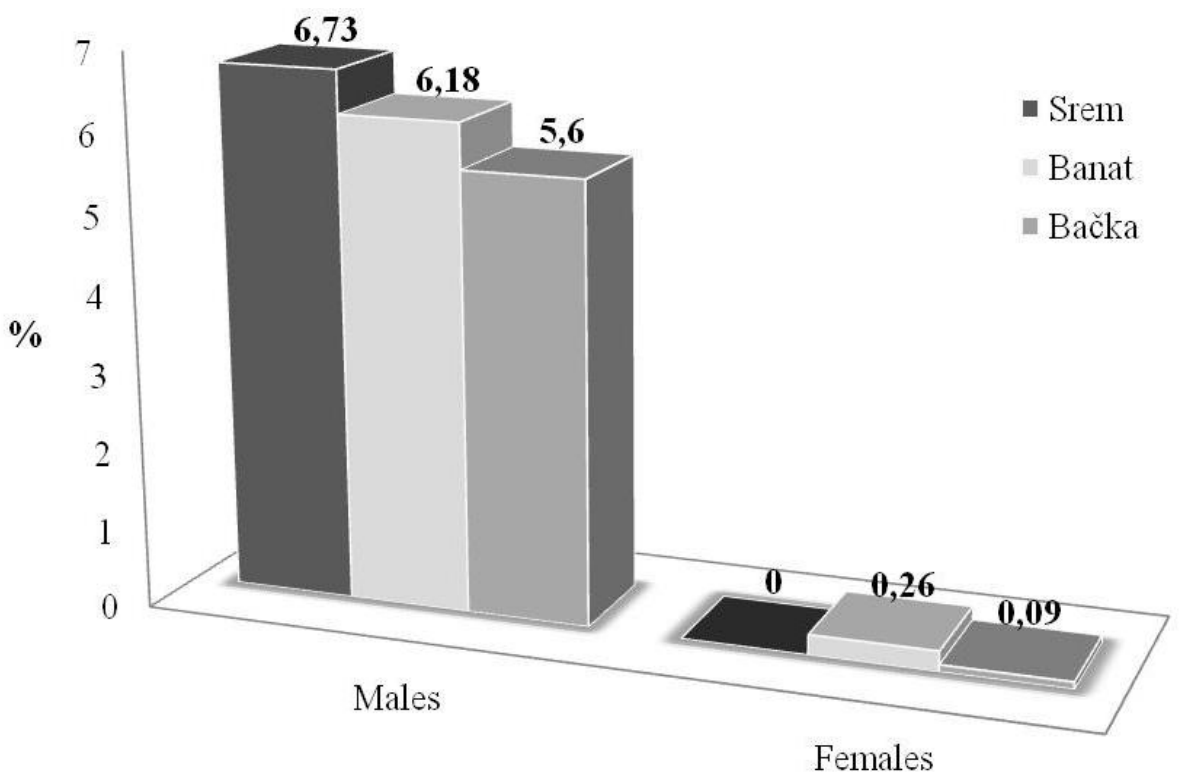

Fig. 1. Prevalence of colour blindness in males and females in three regions of Vojvodina Grafikon 1. Prevalenca kolornog poremećaja kod muškaraca $i$ žena u tri regiona Vojvodine

Prevalence of daltonism in all three regions of Vojvodina is very similar, and in males it ranges from 5.60\% in Bačka to $6.73 \%$ in Srem. In females, a slightly higher percentage of the colour-blind is observed in Banat $(0.26 \%)$, while in the region of Srem not a single case of this disorder is recorded (Figure 1). 
Table 4. Prevalence of colour blindness and certain types of colour blindness

in ethnic groups of males

Tabela 4. Prevalenca kolornog poremećaja kod etničkih grupa muškaraca i žena

\begin{tabular}{lrrrrrrrrr}
\hline & Total & \multicolumn{2}{c}{ Colour blind } & \multicolumn{2}{c}{ Protan } & \multicolumn{2}{c}{ Deutan } & \multicolumn{2}{c}{ Non-classified } \\
& $\mathrm{N}$ & \multicolumn{1}{c}{$\mathrm{n}$} & \multicolumn{1}{c}{$\%$} & \multicolumn{1}{c}{$\mathrm{n}$} & \multicolumn{1}{c}{$\%$} & \multicolumn{1}{c}{$\mathrm{n}$} & $\%$ & \multicolumn{1}{c}{ n } & \multicolumn{1}{c}{$\%$} \\
\hline Serbs & 1852 & 105 & 5.67 & 22 & 1.18 & 58 & 3.13 & 25 & 1.35 \\
Hungarians & 464 & 28 & 6.03 & 2 & 0.43 & 17 & 3.66 & 9 & 1.94 \\
Montenegrins & 99 & 7 & 7.07 & 0 & 0.00 & 6 & 6.06 & 1 & 1.01 \\
Croats & 65 & 6 & 9.23 & 1 & 1.54 & 5 & 7.69 & 0 & 0.00 \\
Slovaks & 246 & 14 & 5.69 & 6 & 2.44 & 6 & 2.44 & 2 & 0.81 \\
Romanians & 63 & 4 & 6.35 & 0 & 0.00 & 1 & 1.59 & 3 & 4.76 \\
Ruthenians & 70 & 9 & 12.85 & 3 & 4.28 & 5 & 7.14 & 1 & 1.43 \\
Roma & 27 & 5 & 18.51 & 3 & 11.11 & 1 & 3.70 & 1 & 3.70 \\
\hline
\end{tabular}

The data for the prevalence of colour disorders in relation to ethnicity (Table 4) are given only for males, as in the female ethnic groups only 3 cases of colour disorders were recorded. It is observed that the prevalence of colour-blindness varies in different ethnic groups. Most colour-blind individuals are noted in the Roma (18.51\%) and the Ruthenians (12.85\%). In other groups the prevalence varies from $5.67 \%$ in Serbs to $9.23 \%$ in Croats. The greatest differences are between ethnic groups with the lowest prevalence (Serbs, Slovaks, Hungarians) and the Ruthenian and Roma ethnic groups where highest frequencies are recorded $(\mathrm{p}<0.05$ and $p<0.01$, respectively). In most ethnic groups deutan disorder is dominant. The exception is the Slovak ethnic group, where the same incidence of both types is recorded, as well as the Roma ethnic group in which the protan type is more common.

Table 5. The heterogeneity of ethnic groups with respect to the observed gene loci Tabela 5. Heterogenost etničkih grupa s obzirom na posmatrane genske lokuse

\begin{tabular}{lcccc}
\hline Phenotype & Allele & $\mathrm{Q}_{\min }-\mathrm{q}_{\max }$ & $\mathrm{q}$ & $\begin{array}{c}\text { Wahlund variance } \\
\sigma^{2} / \mathrm{pq}\end{array}$ \\
\hline Total colourblindness & $\mathrm{cv}$ & $0.056-0.185$ & 0.0617 & 0.00507 \\
Protan & $\mathrm{cv}^{\mathrm{p}}$ & $0.000-0.111$ & 0.0128 & 0.01148 \\
Deutan & $\mathrm{cv}^{\mathrm{d}}$ & $0.016-0.076$ & 0.0343 & 0.00364 \\
\hline
\end{tabular}

The relative frequency of the recessive allele for colour disorder $(\mathrm{cv})$, protan $\left(\mathrm{cv}^{\mathrm{p}}\right)$ and deutan $\left(\mathrm{cv}^{\mathrm{d}}\right)$ type in the ethnic groups of males is shown in Table 5. In the overall frequency of genes for colour disorder (cv), there are also individuals in whom it was impossible to clearly establish the type of anomaly. It is noticeable that the average frequency of the recessive allele (cv) is 0.0617. Somewhat greater variation is observed in the protan type, while lower genetic heterogeneity is detected in the deutan type. Based on these initial data on the genetic composition of ethnic groups, the further analysis of genetic distance was performed.

Dendrogram of the genetic relationship regarding the frequency of the recessive allele for colour-blindness (Figure 2) indicates that there are minor genetic differences in relation to this characteristic. A larger cluster of six ethnic groups characterized by a similar incidence of this disorder is easily observable, while the Roma and the Ruthenians form a somewhat distant group. 


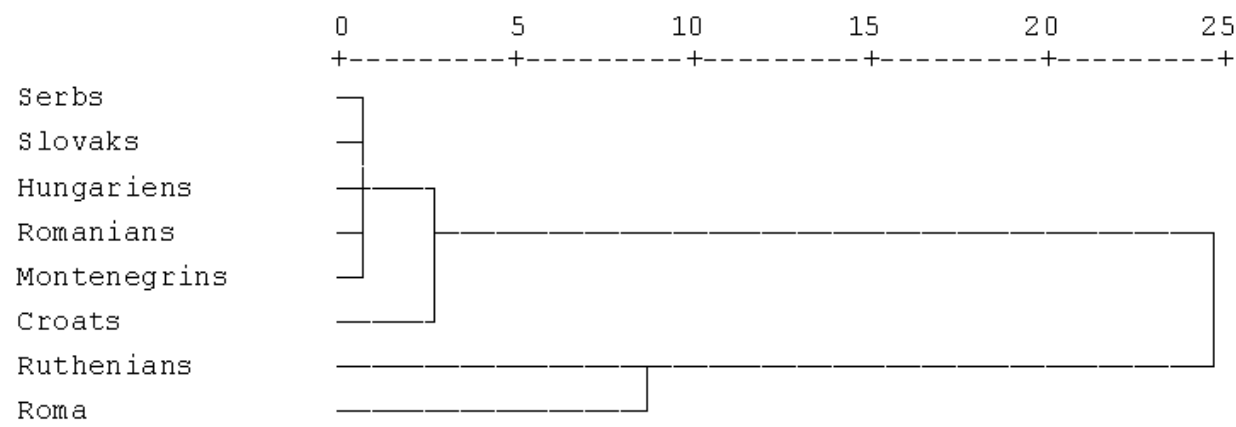

Fig. 2. Dendrogram of the genetic relationship between the ability of ethnic groups to distinguish colors

Grafikon 2. Dendrogram genetske povezanosti etničkih grupa za daltonizam

\section{Discussion}

The present population of Vojvodina exhibits a slightly lower frequency of colourblindness in relation to previous studies of the same population (Stajić, 1973, 1976). This might be a result of migrations which took place in the last decade of $20^{\text {th }}$ century and were caused by the war on the territory of former Yugoslavia. The second possible reason may be found in the greater frequency of cross-ethnic marriages. The genetic heterogeneity of the population of Vojvodina established in this study is relatively small. The dendrogram of genetic relationship indicates minor differences among the ethnic groups. The only groups with a higher frequency of the recessive allele are Roma and Ruthenians, while the other groups are characterized by similar frequencies. Roma ethnic group is special regarding both their origin and lifestyle. Their lifestyle is different from all other ethnic groups in Vojvodina. It is typical of them to constantly move from one place to another, and most often they get married within their own ethnic group. This all has led to very small changes within this ethnic group making their anthropological traits different from those of the other groups living in the regions of Vojvodina.

\section{Conclusion}

For the time being, in the Republic of Serbia colour disorder check-ups are conducted as a part of medical health examinations of children and youth, as well as a part of medical exam for driving licence. Nevertheless, the literature on colour disorders in different regions of Serbia is still sparse. Therefore, this paper attempts to combine the results of recent studies of colour disorders in Vojvodina in order to obtain frequency suitable for the representation on a nationwide scale. In addition, the present study expands the database, which is a necessary prerequisite for further investigations and monitoring of these anomalies.

Acknowledgements. We wish to thank all the students who voluntarily took part in the research without whom this study and its finding would not be possible. 


\section{References}

American Optometric Association. Available from: http://www.aoa.org/patients-and-public/eye-andvision-problems/glossary-of-eye-and-vision-conditions/color-deficiency

Birch J. Worldwide prevalence of red green color deficiency. JOSA A. 2012; 29(3): 313-320. Available from: http://dx.doi.org/10.1364/JOSAA.29.000313

Bogosavljević M. Učestalost daltonizma u Somboru. Diplomski rad, Univerzitet u Novom Sadu, PMF Departman za biologiju i ekologiju; 2008. p.27.

Bukurov B. Bačka, Banat i Srem. Matica Srpska, Odeljenje za prirodne nauke Novi Sad; 1978. p.141.

Cavalli-Sforza LL, Bodmer WF. The Genetics of Human Population, WH Freeman, San Francisco CA; 1971.

Census of Population, Households and Dwellings in the Republic of Serbia, FIRST RESULTS, Statistical Office of the Republic of Serbia, Belgrade; 2011.

Colour Vision Deficiencies in Youths 12-17 Years of Age United States 1974. Data from the National Health Syrvey, Series 11, Number 134, DHEW Publication No.(HRA) 74-1616 US Department of Health, Education and Welfare

Drobac D. Antroposkopske karakteristike dece u Novom Sadu. Diplomski rad. Univerzitet u Novom Sadu, Prirodno - matematički fakultet, Departman za biologiju i ekologiju; 2008. p.36.

Ishihara S. Ishihara's Tests for Colour Blindness, Concise Edition, Tokyo: Isshinkai; 1965.

Karapandžin D. Frekvencija daltonizma u Melencima. Diplomski rad, Univerzitet u Novom sadu, PMF, Departman za biologiju i ekologiju; 2008.

Markov Z. Antroposkopske karakteristike učenika u Zrenjaninu. Diplomski rad, Univerzitet u Novom sadu, PMF, Departman za biologiju i ekologiju; 2008.

Pavlica T. Bioantropološke karakteristike odraslog stanovništva Srema. Magistarski rad, PMF, Institut za biologiju, Novi Sad; 1996. p.110.

Pavlica T. Antropološke karakteristike odraslog stanovništva Bačke i Banata. Doktorska disertacija. PMF, Departman za biologiju i ekologiju, Novi Sad; 2009. p.198.

Pejić Z. Antroposkopske karakteristike adolescenata u Zrenjaninu. Diplomski rad, Univerzitet u Novom sadu, PMF, Departman za biologiju i ekologiju; 2009.

Serbian Statistical Annual. Stanovništvo, nacionalna ili etnička pripadnost, Podaci po naseljima, Republika Srbija, Republički zavod za statistiku, Beograd; 2003.

Simić S. Daltonizam kod studenata Univerziteta u Novom Sadu, Glasnik ADJ 2004; 39: 65-69.

Sharpe LT, Stockman A, Jägle H, Nathans J. Opsin genes, cone photopigments, colour vision and colour blindness. In: Gegenfurtner KR, Sharpe LT editors. Colour Vision: From Genes to Perception; London: Cambridge University Press; 1999: 3-51.

Stajić N. Frekvencija daltonizma u selu Nadalj i prikaz porodice sa protan i deutan alelima. Genetika. 1973;5 (1): 31-38.

Stajić N. Daltonizam kod etničkih grupa u Vojvodini. Doktorska disertacija, Novi Sad, Univerzitet u Novom Sadu; 1976.

National Center for Health Statistics (NCHS). Available from: http://www.cdc.gov/pcd/issues/2008/ Jul/pdf/07_0077.pdf

Tatić S. Antropološke karakteristike stanovnika sela Sajana i Mokrina određivane u porodicama. Magistarski rad, Univerzitet u Novom Sadu, Institut za Biologiju; 2001. 


\title{
PREVALENCA KOLORNOG POREMEĆAJA U VOJVODINI - REPUBLIKA SRBIJA
}

\author{
Tatjana Pavlica, Verica Božić-Krstić, Rada Rakić, Damjana Drobac
}

\begin{abstract}
Sažetak
Nedostatak jednog ili više receptora u čulu vida dovodi do poremećaja u razlikovanju boja. Frekvencija ove anomalije varira između populacija, ali takođe i u okviru različitih regiona jedne zemlje. Cilj rada je bio da se utvrdi frekvencija kolornog poremećaja u regionu Vojvodine - Republika Srbija. U radu su korišćeni podaci istraživanja, u periodu od 1996. do 2009. godine. Predstavljeni su podaci za ukupno 14125 osoba, 6847 muškaraca i 7278 žena. Sva ispitivanja su rađena po istoj metodologiji korišćenjem Išiharinih tablica. Ukupna frekvencija daltonista kod muškaraca iznosi 5,62\%, a kod žena $0,34 \%$. U odnosu na određeni tip ove anomalije, utvrđeno je da se deutan tip javlja češće u odnosu na protan tip. Prevalenca kolornog poremećaja u sva tri regiona Vojvodine je vrlo slična. Genetska heterogenost etničkih grupa, s obzirom na ovo svojstvo je relativno mala. U odnosu na ranija ispitivanja u Vojvodini, utvrđena je nešto niža učestalost kod današnjeg stanovništva. Utvrđene frekvencije se nalaze u granicama evropskih populacija.
\end{abstract}

Ključne reči: Kolorni poremećaj, protan, deutan, Vojvodina, etničke grupe. 